\title{
Assessing the Potential Contribution of Fisheries to Economic Development - The Case of Post-Ebola Sierra Leone
}

\author{
Arthur E. Neiland1, Stephen Cunningham1, Michael Arbuckle², Andrew Baio ${ }^{3}$, \\ Timothy Bostock ${ }^{4}$, Dougoutigui Coulibaly5, Nancy K. Gitonga', Ronan Long ${ }^{7}$, Sheku Sei ${ }^{8}$ \\ ${ }^{1}$ IDDRA Ltd., Gosport, UK \\ ${ }^{2}$ Upper Moutere, New Zealand (Formerly World Bank, Washington DC, USA) \\ ${ }^{3}$ Institute of Marine Biology and Oceanography, Fourah Bay College, University of Sierra Leone, Freetown, \\ Sierra Leone \\ ${ }^{4}$ Canterbury, UK (Formerly World Bank, Washington DC, USA) \\ ${ }^{5}$ GAIPES, Dakar, Senegal \\ ${ }^{6}$ FishAfrica, Nairobi, Kenya \\ ${ }^{7}$ School of Law, National University of Ireland Galway, Galway, Ireland \\ ${ }^{8}$ Ministry of Fisheries and Marine Resources (MFMR), Freetown, Sierra Leone \\ Email: neiland@iddra.org
}

Received 26 April 2016; accepted 14 June 2016; published 17 June 2016

Copyright (C) 2016 by authors and Scientific Research Publishing Inc.

This work is licensed under the Creative Commons Attribution International License (CC BY).

http://creativecommons.org/licenses/by/4.0/

(c) () Open Access

\section{Abstract}

This paper examines the potential contribution of the fisheries sector to national economic development in Sierra Leone, following the cessation of the recent Ebola virus disease (EVD). The tragic deaths of some $\mathbf{4 0 0 0}$ persons, as a direct result of this epidemic, have also been accompanied by serious economic disruption to one of the world's poorest countries, amounting to a loss of over USD 1 billion (20 per cent of annual Gross Domestic Product, GDP). Based on recent work undertaken by the New Partnership for Africa's Development (NEPAD), an assessment was made of the potential contribution of one of the country's major natural resource sectors-fisheries-to future economic recovery. It was confirmed that the fish resources of Sierra Leone have an estimated capitalised economic value of USD 735 million, and could potentially make an increased contribution to GDP under suitable conditions, over and above the current estimated level of 10 per cent. However, our results also show that with an overall "readiness assessment" score of $41 / 100$, the sector is unlikely to realise its full potential unless a number of specific areas are addressed (based on analysis valid up to January 2016). These include an improvement in fisheries economic assessment, the upgrading of the fisheries governance and management framework, and the establishment of a fisheries development strategy and implementation plan to channel future investments and interventions in an appropriate sequence. Particular attention should be 
given early on to an increase in the quality and capacity of both public and private sector organisations relevant to roles and functions within a general process of fisheries sector reform. Finally, the fisheries policy evaluation approach used here is novel. While it has been applied to Sierra Leone for the intrinsic interest of that case, this demonstration also shows that it could be applied elsewhere in the future when reviewing fisheries policy.

\title{
Keywords
}

\author{
Sierra Leone, Capture Fisheries, Economic Development, Evaluation Methodology, Ebola Virus \\ Disease (EVD)
}

\section{Introduction}

From the beginning of 2014, the devastating impact of the Ebola virus disease (EVD) on Sierra Leone and other West African countries, in particular Guinea and Liberia, was widely reported [1] [2]. With 11,284 human deaths (by August 2015) and significant accompanying disruption caused to the lives of many families and communities in the region, the top priority for the national governments concerned, and their development partners, was to control and then eradicate the disease [3] [4].

The epidemic has also had a major impact on development progress. According to the World Bank Group (2015), the Ebola crisis has crippled the economies of Guinea, Liberia and Sierra Leone, leading to a loss of at least USD 2.2 billion in foregone economic growth in 2015, along with job losses, smaller harvests and food insecurity [5].

In the specific case of Sierra Leone, the World Health Organisation (WHO) announced on 7 November 2015 that Ebola virus transmission had stopped, with a regional death toll of 11,300 persons (3995 persons in Sierra Leone alone) [6]. The country is currently under enhanced surveillance in order to manage the residual risks of EVD reintroduction or re-emergence. In looking to the future, it is well-recognised that re-building the economy will be one of the most important challenges. In 2014, economic growth in Sierra Leone fell by more than half to 4\%, the total GDP loss in 2015 is estimated at nearly USD 1 billion, and in response the Government of Sierra Leone has also prepared an Economic Recovery Strategy (ERS), while international donors, such as the World Bank Group, have committed major funding to assist trade, investment and employment [7].

Sierra Leone, like many countries in West Africa, is well-endowed with natural resources including mineral ores, forests and fish stocks, which could form the basis of a productive economy and a prosperous society [8] [9]. However, Sierra Leone's development track-record since independence in 1960 has been relatively weak, and despite some improvements since the end of the civil war in 2002, it is one of the poorest countries in the world [10] [11]. There can be no doubt that improving upon this performance is critically important for economic recovery during the current post-Ebola period.

In the following paper, the future prospects for one of the major economic sectors in Sierra Leone-fisheries - will be assessed. Drawing upon the detailed work of a collaborative programme-the West African Pilot Project (WAPP) - involving both national and international experts, and coordinated by the African Union's New Partnership for Africa's Development (NEPAD), between 2012 and 2014, the main factors involved will be identified and examined.

The analysis presented in this paper is considered to be highly relevant to the future design and implementation of a long-term fisheries development strategy to support economic recovery for post-Ebola Sierra Leone.

\section{Approach}

The approach used in this paper has five main components as follows:

\subsection{Background}

To set the scene, an overview of the national context and recent development history of Sierra Leone is presented, along with the key features of the fisheries sector. 


\subsection{Expert Panel and Score-Card Methodology}

The findings of an expert panel working as part of the NEPAD-WAPP (2012-14) are presented. The panel was tasked to make an assessment of the potential contribution of fisheries to economic development in Sierra Leone in the future (the results remain valid up until January 2016).

An expert panel methodology was chosen for a number reasons including: a) the advantage of using available expert knowledge to examine complex situations and issues; b) the ability to undertake in-depth and meaningful interaction between experts from different disciplines and drawing on relevant experiences; c) the overall independence and impartiality of the panel members; and d) the consensus-building process involved, confers a high level of credibility to the results. The value of an expert panel approach has been widely recognised by many organisations, for example by the European Commission, especially for Foresight Exercises [12].

Five steps were implemented as follows: i) the expert panel (the authors) was assembled as part of the work of the NEPAD-WAPP including a range of appropriate experts (in economics and fisheries management) with experience of fisheries development in Sierra Leone, other parts of Africa, and internationally; ii) arrangements were made for the panel members to meet in Freetown on four occasions; iii) the assessment of the fisheries sector and its potential contribution to economic development was undertaken using a 10-point score card, developed by the panel members, who were then asked to deliberate carefully over the results and to reach a consensus; iv) the expert panel collated and analysed relevant background information to support the overall assessment process; and v) the results were summarised in the current paper, as a contribution to future evidence-based thinking on fisheries development strategy in Sierra Leone and elsewhere in Africa.

The 10-point score card (called the "Freetown Fisheries Framework", after Sierra Leone's capital where the work was undertaken) (Table 1) consists of a series of inter-related key questions leading to an overall "state of readiness" assessment.

In Section 4, for each question in turn, a brief introduction is provided, followed by the assessment score (out of 10) and a summary of the supporting information and analysis. The total sum of the scores (shown as a percentage), assuming that each factor has an equal weight, provides an indication of the likely success of fisheries development in Sierra Leone and a positive impact on national economic development (the "readiness assessment”). A score of $100 \%$ would indicate a perfect state of readiness. The relative scores between key factors indicate where intervention and support are most needed.

\subsection{Entry Point-Economic Value}

The current analysis focuses on the contribution of fisheries to the national economy, and the factors which will enable or constrain this relationship. The initial entry-point point, therefore, will be to examine the potential sustainable economic value of the exploitable fish stocks. It is known that productive and well-managed fisheries can make an important sustainable contribution to economic growth. Countries with strong economic

Table 1. The Freetown Fisheries Framework: 10-point score card for fisheries development potential.

\begin{tabular}{ll} 
No. & Key Questions \\
\hline 1 & Has the sustainable economic value of the fish stocks been determined? \\
3 & Is the national vision and strategy for the sector appropriate and agreed? \\
4 & Is there a well-defined fisheries policy? \\
5 & Does the fisheries law provide an enabling framework? \\
6 & Is there a high degree of policy coherence? \\
7 & What is the status of the fisheries management systems? \\
8 & Is there a well-defined work-plan for policy implementation? \\
9 & Is there sufficient institutional capacity for implementation? \\
10 & Is there appropriate finance and investment available? \\
\hline
\end{tabular}


growth, coupled with good governance, in general, also show an increase in prosperity, social welfare and poverty reduction [13].

In other words, the current paper seeks to emphasise the critical and inclusive role which fisheries can play in the wider economy and for the benefit of all citizens of a country. The direct benefits associated with participation in fisheries (e.g. food supply, employment, income) have already been well-documented in Sierra Leone and many other countries in West Africa by the Food and Agriculture Organisation (FAO) of the United Nations, for example [14]. Managing fisheries for the benefit of all citizens requires a different type of policy approachone which looks beyond the conventional boundaries of the sector-that recognises the hitherto undervalued potential wealth of fish resources, which utilises innovative and proven methods of fisheries management, that includes all fishery types and scales of activity, and which seeks to strengthen linkages between fisheries and other parts of the wider economy [15]. These themes are coherent with the new concepts of the "Blue Economy" and "Blue Growth" [16].

\subsection{Sequencing and Fisheries Development}

The order of the ten key questions within the Freetown Fisheries Framework is important-the sequencing of actions and interventions is a, if not the, key determinant of fisheries development success. In particular, empirical studies have shown that sectoral development will be dependent on establishing the appropriate core governance framework (questions 2 - 7) - a process consisting of agreeing a sectoral vision, followed by a coherent policy, backed up by an enabling legal framework, then the design and implementation of fisheries management systems [17] [18]. In reality, the remaining elements (institutions, finance and support) (questions 8 - 10) should be considered in parallel to the core governance sequence, but for simplicity sake here, they have been included at the end.

\subsection{Reaching Conclusions and Identifying Future Priorities}

A final section provides a set of conclusions and identifies future priorities for development intervention and investment.

\section{National Context and Fisheries Sector}

\subsection{National Context}

Sierra Leone is a country in West Africa (71,740 sq km, 6.2 million people) which shares international borders with Liberia and Guinea [19].

Although richly endowed with natural resources including mineral ores, forests and fish stocks, Sierra Leone has a relatively small economy (nominal Gross Domestic Product (GDP) USD 4.8 billion), high levels of poverty (over 53\%, poverty headcount) and is ranked number 183 out of 187 countries on the Human Development Index [10] [11].

Between 1991 and 2002, this relatively fragile democratic country was overtaken by a devastating civil war, representing a major set-back to national development.

In the post-conflict years, significant levels of aid and foreign investment have flowed into the country, accompanied by clear signs of economic recovery (GDP growth in excess of 11\% in 2014), and positive impacts on health, education and infrastructure development [8]-[10].

More recently, the EVD has killed nearly 4000 people and severely inhibited the economy and trade (GDP growth has dropped to less than $4 \%$, representing a total loss of US\$ 1 billion), and deterred and delayed private investment and aid-related programmes [1] [10].

\subsection{Fisheries Sector}

Sierra Leone has a diverse and valuable array of fish stocks in marine and inland environments, which are exploited mainly through fishing and a limited number of aquaculture systems [20].

According to the Ministry of Fisheries and Marine Resources (MFMR) [20], the current total annual fisheries production is about 150,000 tonnes. The marine artisanal fishing sub-sector, characterized by small-scale, inshore, low technology operations, accounts for the bulk of this catch $(120,000 \mathrm{t}$, valued [first sale only] at USD 
100 million per year). The marine industrial fishing sub-sector catches an estimated 24,000 $\mathrm{t}$ (valued at USD 25 million per year). Both inland fisheries and aquaculture production are relatively small in comparison.

It should be noted that the official statistics (above) use a set of financial indicator values (e.g. gross catch value based on first sale market prices and landings, costs are not included). While this approach provides a good starting point for understanding the value of the sector (assuming that the basic catch and market statistics are accurate), the next level of analysis (using formal economic approaches to assess expenditures, profitability and net returns) is needed to better understand the performance of the sector, and its contribution to the economy overall (for an overview of GDP calculation see The Economist (2014) [21]).

The fisheries sector is estimated to provide employment and a source of livelihoods for over 500,000 people, mainly in coastal communities. Fish is the most important source of animal protein for the majority of the population. Annual fish exports are valued at USD 2.5 million and fishing licence fees amount to USD 2.5 million per year.

In terms of domestic revenue collection by the Government of Sierra Leone, the fisheries sector contributed USD 34 million (1 per cent of total revenue) in 2014 as shown in Table 2. This represents a doubling of the revenue collected in 2013.

The contribution of the fisheries sector to GDP in Sierra Leone was estimated to be 10.2 per cent in 2013 (Table 3). The largest contribution came from agriculture, hunting and forestry (42.5 per cent) and then mining (11.6 per cent).

GDP figures underestimate the economic importance of the fish resources, because fisheries sector GDP is restricted to fish catching activities alone. The GDP generated by downstream secondary economic activities such as fish processing and trading which depend on healthy fish stocks are attributed to other sectors of the economy.

The MFMR has overall responsibility for the sector. Until recently, fisheries policy focused on increasing production (the physical weight of fish landed) through technological improvements in catching methods (new boats and fishing gear), although the importance of fisheries management is now also being emphasised.

Decision-support comes mainly from university-based research organizations (e.g. Institute for Marine Biology and Oceanography, IMBO) and from international donor-supported projects.

The private sector consists of a small domestic industrial sector ( $<10$ companies) and a very large artisanal sector (over 500,000 persons) with two main representative organizations, the Sierra Leone Artisanal Fishermen's Union (SLAFU) and the Sierra Leone Amalgamated Artisanal Fishermen's Union (SLAAFU). The Third Sector is small, with few active Non-Government Organisations (NGOs). Furthermore, there is significant foreign involvement in the private sector, with fishing operators (from Asia and Europe) granted licences to fish under joint-ventures partnerships with local agents. It is thought that a significant quantity (and value) of the catch taken by foreign vessels is trans-shipped at sea, and is not landed or processed onshore in Sierra Leone (statistics regarding these flows are limited).

Illegal, Unreported and Unregulated (IUU) fishing is also thought to be significant in Sierra Leone. In particular, unlicensed foreign vessels operate in the largely unprotected areas of Sierra Leone's Exclusive Economic

Table 2. Sierra Leone-domestic revenue collection (2014) ${ }^{\mathrm{a}}$.

\begin{tabular}{cccc}
\hline \multirow{2}{*}{ Area } & \multicolumn{3}{c}{ Amount of Revenue } \\
\cline { 2 - 4 } & Sierra Leone Leones (Le'M) & USD Millions & 4 \\
\hline Road Vehicles & 87,616 & 199 & 3 \\
Other Departments & 64,642 & 147 & 1 \\
Fisheries & 14,929 & 34 & 9 \\
Minerals & 209,413 & 476 & 21 \\
Goods and Service Tax & 459,095 & 1043 & 23 \\
Customs and Excise & 506,816 & 1152 & 40 \\
Income Tax & 895,681 & 2036 & 100 \\
Total & $2,238,192$ & 5087 & \\
\hline
\end{tabular}

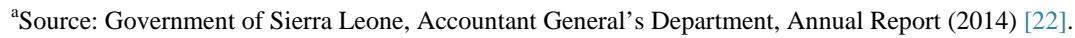


Table 3. Sierra Leone-gross domestic production (GDP)-\% composition ${ }^{\mathrm{a}}$.

\begin{tabular}{|c|c|c|}
\hline \multirow{2}{*}{ Area } & \multicolumn{2}{|c|}{$\%$ GDP } \\
\hline & 2008 & 2013 \\
\hline 1) Agriculture, hunting, forestry and fishing & 56.3 & 52.7 \\
\hline 1.1.) Of which fishing & 8.9 & 10.2 \\
\hline 2) Mining & 3.7 & 11.6 \\
\hline 2.1.) Oil & n.a. & n.a. \\
\hline 3) Manufacturing & 2.6 & 2.1 \\
\hline 4) Electricity, gas and water & 0.2 & 0.2 \\
\hline 5) Construction & 1.7 & 1.3 \\
\hline 6) Wholesale and retail trade, hotels and restaurants & 9.2 & 9.1 \\
\hline 6.1.) Of which hotels and restaurants & 0.4 & 0.4 \\
\hline 7) Transport, storage and construction & 6.7 & 4.6 \\
\hline 8) Finance, real estate and business services & 7.9 & 6.6 \\
\hline \multicolumn{3}{|l|}{ 9) Public administration, education, health and social work } \\
\hline Community, social and personal services & 3.6 & 4.9 \\
\hline 10) Other serices & 8 & 6.9 \\
\hline GDP at basic prices/factor cost, Total & 100 & 100 \\
\hline
\end{tabular}

${ }^{\mathrm{a} S o u r c e: ~ A f D B, ~ O E C D ~ a n d ~ U N D P ~(2014) ~[23] . ~}$

Zone (EEZ) closest to the High Seas boundary and at the maritime borders with Guinea and Liberia. The economic value of the fish lost to IUU for Sierra Leone is estimated to be at least USD 30 million annually [24].

\section{Fisheries Development Prospects-10-Point Score Card Assessment (The Freetown Fisheries Framework)}

In the following section, the findings of the expert panel will be presented. At the end, a total percentage score will provide the overall readiness assessment for fisheries development in Sierra Leone.

\subsection{Has the Sustainable Economic Value of the Fish Stocks Been Determined?}

\section{Introduction}

The sustainable economic value of the fish stocks of Sierra Leone is the overall starting point for this assessment. Fish stocks can be viewed as a form of renewable "natural capital”. The economic activities relating to fisheries exploitation will contribute to GDP. Furthermore, the economic value (surplus) generated, if re-invested, can help to drive economic growth, and in turn social development and poverty reduction. It is important early on, therefore, to have some estimation of the quantity and value of the natural resources (fish stocks) which might be exploited (fished), and contribute to the national economy, and underpin national development plans.

In theory, building a national development programme upon a foundation of renewable natural capital—such as fish stocks (or forests)_capable of generating economic benefits (and investable surplus) year after year (compared to non-renewable gold, petroleum and other minerals), through appropriate exploitation, is a very attractive proposition to most governments. On the other hand, it should also be recognised that, for various reasons, resource abundance can be difficult to translate into national development, as examined by the many publications in the international literature on the so-called "resource curse" [25].

\section{Assessment score}

The expert panel awarded an assessment score of 4/10 for the extent to which the sustainable economic value of the fish stocks has been determined for Sierra Leone. There is some existing knowledge, as outlined below, but it needs to be significantly upgraded and then disseminated and explained carefully to all stakeholders and 
decision-makers.

\section{Supporting information and analysis}

In the case of the fish resources of Sierra Leone, there was no economic valuation reported in the official statistics (above). A preliminary estimate, to plug this gap, was made (by the current authors) in an earlier project. The potential total economic (capitalised) value of the exploitable marine fish stocks (data for freshwater and aquaculture were limited) was estimated at USD 735 million, capable of producing an annual economic return of USD 59 million [24]. However, generating this return would depend upon an appropriate and effective fisheries management system (e.g. with the clear objective of maximising economic benefits, within a use rights-based framework) being in operation (along with a well-functioning economy) (Table 4, Type I). By comparison, under the conventional fisheries management arrangement (Type II) — prevalent in many parts of the world—with a focus on fish production maximisation, and government-controlled ("top-down") management-little or no economic rent will be generated.

These contrasting outcomes have been revealed by both theoretical and empirical studies of many fisheries throughout the world [15] [18]. The implementation of Type II systems inevitably lead to both the economic and biological overexploitation of the fishery in the long-run. The underlying process involved has been recognisedfishers operate under weakly defined use-rights (e.g. short-term catch quotas) creating incentives to compete for fish catches and to build greater fishing capacity (e.g. fleet size), which leads to overcapacity (overcapitalisation) and overfishing. At the same time government systems and regulations alone are usually unable to respond to or control the imbalance between fishing activity and fishing opportunities, under dynamic fishery and market conditions. By comparison, fisheries management systems which are underpinned by strong use-rights and stakeholder (fisher) involvement, often involving collective action, have proved to be more successful in achieving productive and sustainable fisheries.

The preliminary economic valuation presented (Table 4) relates only to marine fish stocks in Sierra Leone. However, this certainly indicates that the fisheries sector could make an important contribution to GDP. The analysis has been updated for 2014, in order to compare the potential GDP contribution of the sector given the current status of the fisheries, which are characterised by a relatively low level of production, low financial turnover and low levels of profitability (Table 5).

The role of well-managed fisheries, generating economic rent and contributing increasingly to GDP is also integrally related to other "benefits" which can be identified and valued including sustainable employment and food security (Table 5). It is estimated that at present that the "artisanal" fishing sub-sector in Sierra Leone contributes significantly to employment and food security (both fish as a food supply and wage income to purchase food), particularly for coastal communities. The "industrial" fishing sub-sector makes a limited contribution to employment and food security (although some industrial vessels land by-catch fish at Freetown, and this enters

Table 4. Sierra Leone-comparison between marine fisheries management arrangements.

\begin{tabular}{|c|c|c|c|c|}
\hline \multirow{2}{*}{ Fishery } & \multicolumn{2}{|c|}{ Management Type (I) ${ }^{\mathrm{a}, \mathrm{d}}$} & \multicolumn{2}{|c|}{ Management Type (II), } \\
\hline & Annual Landings (t) & $\begin{array}{l}\text { Value (Ex-vessel) } \\
\text { (USD millions) }\end{array}$ & Annual Landings (t) & $\begin{array}{l}\text { Value (Ex-vessel) } \\
\text { (USD millions) }\end{array}$ \\
\hline Artisanal catch & 46,860 & 41.5 & 30,000 & 26.6 \\
\hline Industrial small pelagic & 70,000 & 62 & 25,000 & 22.1 \\
\hline Industrial large pelagic & 15,000 & 19.5 & 10,000 & 13 \\
\hline Industrial demersal & 18,000 & 30.2 & 10,000 & 16.8 \\
\hline Shrimp & 2600 & 20.8 & 2000 & 16 \\
\hline Other industrial & 10,000 & 22 & 10,000 & 22 \\
\hline Total & 162,460 & 196 & 87,000 & 116.5 \\
\hline Resource rent ${ }^{\mathrm{c}}$ & & 59 & & 0 (Zero) \\
\hline Capitalised value $^{\mathrm{c}}$ & & 735 & & 0 (Zero) \\
\hline
\end{tabular}

${ }^{a}$ Maximization of economic benefits, under a use rights framework. 'baximization of fish production, under a government-controlled "top-down” framework. 'Resource rent calculated as 30\% of annual turnover, capitalised value @8 per cent over 10 years. ${ }^{\mathrm{d}}$ Source: DFID, World Bank, FAO Report (2007) [24]. 'Estimation of catch levels and composition under conditions of severe overexploitation based on the authors' assessment. 
Table 5. Sierra Leone-comparison of fisheries performance and GDP contribution.

\begin{tabular}{|c|c|c|}
\hline \multirow{2}{*}{ Fishery Sub-Sector } & \multicolumn{2}{|c|}{ Management Arrangements } \\
\hline & 2014 (Fisheries Management Type II) & Potential (Fisheries Management Type I) \\
\hline \multicolumn{3}{|l|}{ Marine Fishery Sub-Sector } \\
\hline \multicolumn{3}{|l|}{ [a] Artisanal } \\
\hline Catch (t) & 120,000 & 46,860 \\
\hline Financial value (USD millions) & 100 & 41.5 \\
\hline Fishing enteprise profitability & Low & High \\
\hline Economic rent (USD millions) & 0 & 16 \\
\hline Employment & High & High \\
\hline Food security contribution & Important & Important \\
\hline Fishery status (benefit levels above) & Unsustainable & Sustainable \\
\hline \multicolumn{3}{|l|}{ [b] Industrial } \\
\hline Catch & 24,000 & 115,600 \\
\hline Financial value & 25 & 154.5 \\
\hline Fishing enterprise profitability & Low & High \\
\hline Economic rent (USD millions) & 0 & 43 \\
\hline Employment & Low & High \\
\hline Food security contribution & Medium & High \\
\hline Fishery status (benefit levels above) & Unsustainable & Sustainable \\
\hline \multicolumn{3}{|l|}{ [c] Total Overall (Marine) } \\
\hline Catch & 144,000 & 162,460 \\
\hline Financial value (USD millions) & 125 & 196 \\
\hline Fishing Enterprise Profitability & Low & High \\
\hline Economic rent (USD millions) & 0 & 59 \\
\hline Employment & High & High \\
\hline Food security contribution & High & High \\
\hline Fishery status (benefit levels above) & Unsustainable & Sustainable \\
\hline [d] Domestic revenue collection (USD millions) & 34.1 & $>34.1$ \\
\hline [e] GDP Contribution (\%) & 10.2 & $>10.2$ \\
\hline
\end{tabular}

${ }^{a}$ Source: NEPAD team (the authors) assessment based on field observations in Sierra Leone and key publications [20] [23] [24].

local markets). The major issue, of course, is that these levels of benefit flows, while important in the short term, and particularly in this time of crisis for Sierra Leone, are not sustainable in the long-run given the fisheries management system (Type II) which is currently in place, and the lack of implementation effectiveness since both government and sector institutional arrangements are weak.

By comparison, under appropriate management (Type I), and some re-structuring of the fisheries sector (Table 5), the resulting improvement in performance (profitability and economic rent generation) would catalyse long-term improvements overall. In particular, the use of the investable economic surplus within the coastal economy by both profitable artisanal and industrial fishing enterprises would generate down-stream primary and secondary employment, and contribute to food security (through fish supply, wage incomes). The key feature of this outcome will be valuable, sustainable benefits which can be grown even further as the economy develops.

The "potential" fishery arrangements (Table 5) will be dependent on some re-structuring of the fishery sector. The artisanal fleet, which has expanded rapidly without any control, will be reduced to a level where catches are 
sustainable and profitability is ensured; the industrial fleet will be expanded to access a broad range of fishing opportunities; both artisanal and industrial fleets will be included in an integrated fisheries management system, focused on well-defined fisheries management units, and the use of management instruments and institutional arrangements that are appropriate to the features of the fisheries involved and associated stakeholders (objectives, scale, diversity, stocks types, gears etc.).

The need to understand the long-run dynamic relationships between effective fisheries management schemes, improved fisheries performance and different benefit streams is critical for policy-makers in Sierra Leone. In the short- to medium-term, the reform process required to develop new fisheries management systems and a new sector structure will have to be worked out carefully, and this will need appropriate funding to support the major changes, including appropriate mitigation schemes for any stakeholders affected.

\subsection{What Is the National Vision and Strategy for the Sector?}

\section{Introduction}

In many countries where fisheries sector reform has been attempted, an important early phase has involved working with a full range of stakeholders to set out a new national vision and development strategy. Through facilitated workshops and meetings, stakeholders are given the opportunity to express their views and contribute to the identification of opportunities and priorities. Although this process can often be difficult and protracted, it can also be very worthwhile if a common vision and strategy emerges, with commitment and support from a majority of the stakeholders involved.

\section{Assessment score}

The expert panel awarded an assessment score of 7/10 for the national vision and strategy for the fisheries sector in Sierra Leone. The panel agreed with a recent review carried out under the NEPAD programme (2013) that the current vision and strategy document provides an adequate basis for sectoral development and future reforms, and has been derived from a legitimate stakeholder engagement process [30].

\section{Supporting information and analysis}

In Sierra Leone, a number of attempts at developing a national vision and strategy have taken place. The current vision and strategy emerged from the MFMR decision (2007) to re-visit the "Fishery Policy of Sierra Leone 2003" [26]. As a result between 2007 and 2010, the MFMR and IMBO, with support of the EU-funded "Institutional Support for Fisheries Management (ISFM) Project” plus an FAO expert, undertook consultations and stakeholder dialogue, leading to a series of draft policy documents which were presented to National Scientific and Technical Committee. This led to the production of the "Policy and Operational Framework for Fisheries of Sierra Leone" [27] which was validated by an enlarged meeting of stakeholders on 11 March 2010. The "vision" for the future of the fisheries of Sierra Leone (derived from the stakeholder consultation process) focuses on a key outcome as follows: "Biologically sustainable fisheries resources that are robust and diverse, contribute to poverty reduction and wealth generation, are managed on the basis of good governance, are sustainable and economically viable, contributing to the economic base of coastal and riverine communities, and effectively involve all interest groups in appropriate fisheries management" [27].

\subsection{Is There a Well-Defined Fisheries Policy, with Clear Objectives?}

\section{Introduction}

A fisheries policy should define a set of objectives (and outcomes) for the sector and the implementation process (and instruments) for achieving them, along with defining the roles and responsibilities of the relevant organisations and institutions involved. In this section, the main focus will be the objectives and outcomes. The institutional and implementation mechanisms will be addressed further below.

\section{Assessment score}

The assessment score awarded for the national fisheries policy is $7 / 10$. While there is still scope to improve the policy document, it provides a good basis for the future in line with international best practice.

\section{Supporting information and analysis}

As mentioned earlier, until recently fisheries policy in Sierra Leone adopted a conventional productionoriented and technology-driven approach to fisheries development, with an associated high risk of both economic and biological overexploitation for the major fish stocks.

The "Policy and Operational Framework for the Fisheries of Sierra Leone, Ministry of Fisheries and Marine 
Resources (MFMR) (March 2010)” [27] super-ceded the earlier Fishery Policy of Sierra Leone (2003) [26]. This new policy is more in line with international best practice. There is a defined outcome: "Ecologically sustainable and economically efficient fisheries in Sierra Leone", and five policy objectives: Conservation and sustainable use, Increased co-management through committed, Informed and involved stakeholders, Diversification and increase in international trade of fish and fish products, Functional extension service capable of delivering cost-effective and efficient management tools, and Promote sustainable aquaculture production.

With respect to these five objectives, it is also stated clearly that

"Conservation of living aquatic resources and habitat (in both marine and freshwater environments), and rebuilding of resources and restoration of habitat where necessary, will be the highest priority for the management of all fisheries. Within the limits of available knowledge, all fishing activities will be conducted in a manner that leads to sustainable levels of resource use". (p. 10)

The "Expected Overall Outcome of the Policy Framework" is stated as follows:

"The overall focus will aim at promoting the attributes of good governance in sustainable fisheries management, combating illegal, unreported and unregulated (IUU) fishing, promoting economic value addition to the fisheries, augmenting capture fisheries production through sustainable development of aquaculture, consistent with the National Agenda for Change. The overall outcome can be summarized as: Ecologically sustainable and economically efficient fisheries in Sierra Leone". (p. 11) [27]

The policy document set outs principles and strategies intended to guide policy implementation. While this section contains many relevant areas, it is unwieldy. It would benefit from the application of a planning tool, such as a logical framework approach (LFA), in order to make the links between outputs and inputs, indicators and measurements, issues and context, risks and assumptions.

Overall, specific policy objectives are clearly defined. The policy framework affirms that conservation and sustainable use of the fish stocks is the priority for the management of fisheries in Sierra Leone (p. 16). The overall expected outcome is "Ecologically sustainable and economically efficient fisheries in Sierra Leone". Adequate supporting information on the Future Vision, and on key principles and strategies for policy implementation, derived from the detailed stakeholder and expert consultation process, is also provided.

\subsection{Does the Current Fisheries Law Provide an Enabling Framework for Fisheries Development?}

\section{Introduction}

As a core component of fisheries governance arrangements, an appropriate and effective fisheries legal framework should guide policy implementation and help to operationalise the fisheries management system applied, consisting of sets of rules and regulations at different levels of applicability, and defining the rights and responsibilities of all stakeholders involved.

\section{Assessment score}

The overall assessment for the fisheries law is 2/10. The current framework in Sierra Leone shows serious weaknesses and the proposed new law (or revisions) has not been approved by government.

\section{Supporting information and analysis}

A Fisheries Law document ("Republic of Sierra Leone, Draft Fisheries and Aquaculture Bill (2011)”) [28] was developed under the FAO Technical Cooperation Programme on Modernising Sierra Leone's Fisheries Legal Framework. This was proposed to replace the Fisheries Act 1994 [29]. The Draft Bill awaits final endorsement by Parliament. In 2012, the NEPAD team was requested by the MFMR to review the draft Bill, as part of a policy review.

The proposed Draft Fisheries Bill (2011) covers a broad range of areas, which should support and enable the implementation of fisheries policy. It can be argued, however, that the current framework and content shows some specific and important weaknesses. First, the purpose of the law is not clearly defined (and supported with a set of key principles). Second, a significant degree of authority resides within the MFMR, and there is a need to delegate and share power more widely. Third, the law tends to be more restrictive in nature, rather than enabling, in terms of how fishermen and fishing companies could pursue their fishing operations.

Between 2013-14, the NEPAD team produced a revised version of the Fisheries Bill (2011), to address the concerns identified (above), and to enable the application of key principles, highlighted in the current draft Fisheries Policy (above), including a focus on rights and wealth, co-management, and stakeholder participation in 
policy-making and fisheries management [30] [31]. In terms of international best practice, this revised law includes a set of core elements as follows - a clear purpose statement, an assertion of national sovereign rights to the Exclusive Economic Zone (EEZ), definition of a process of decision-making under designated fisheries management systems, definition of transparent processes for specifying and authorising defined fishing units, establishment of transparent and accountable processes for defining roles and responsibilities, with regards to management and rights, a process for setting Total Allowable Catch (TAC), and defining catch quota allocation and management measures, definition of enforcement procedures and penalties, definition of foreign ownership provisions, and provision for Public-Private Partnership Agreements. To date, the proposed Fisheries Bill (2011) has not been passed by Parliament, and the revised document produced by NEPAD [31] has not been formally endorsed by the MFMR.

\subsection{Is There a High Degree of Policy Coherence?}

\section{Introduction}

Policy coherence means that policies are coordinated and complementary and not contradictory. It is an important characteristic of good governance. In the case of ineffective government and a lack of policy coherence, impacts may include weak policy performance and even direct conflict between policies. Weak policy performance may lead to the wastage (or inefficient usage) of national resources. Government authorities can lose their legitimacy and credibility if policy coherence issues are not addressed.

\section{Assessment score}

The assessment score for policy coherence is 4/10. While Sierra Leone shows some evidence of "internal” policy coherence concerning the new fisheries policy (2010), there are also serious concerns over "horizontal” coherence with other policies on poverty reduction, fiscal arrangements and governance reform.

\section{Supporting information and analysis}

There are concerns over fisheries policy coherence in Sierra Leone.

Regarding "internal" coherence (is the policy coherent within itself?), the new "Fisheries Policy and Operational Framework (2010)", show a good level of coordination and continuity. There is a single and well-defined outcome, that is, "Ecologically sustainable and economically efficient fisheries in Sierra Leone". The five main policy objectives are defined to achieve and support this outcome. Of course, this is a new policy framework, and the extent to which the implementation of the five policy objectives will remain cohesive has yet to be tested. One of the main concerns is likely to be the relationship between "artisanal” and "industrial” fishing, and the extent to which both can be managed under a common system (see Section 6 below).

In terms of "horizontal" policy coherence (is the policy coherent with other policies operating at the same level?), fisheries policy in Sierra Leone interfaces with a wide range of other policies relating to sectors and organisations. Three important future areas include the following.

First, poverty reduction strategy and policy, which is the main theme of the Government of Sierra Leone's (GoSL) “The Agenda for Prosperity” (the Third Generation Poverty Reduction Strategy Paper) [32]. Within this large and complex document, the fisheries sector is included under "Pillar 1. Economic Diversification to Promote Inclusive Growth". The overall goal is "A sustainable fisheries sector which primarily ensures food security and increased jobs for Sierra Leonean men and women, and in addition begins to maximise opportunities for value addition and export to strategic and competitive markets”. The strategic objectives are i) to increase the supply of fish for the domestic market by at least $15 \%$ annually particularly from the semi-industrial, artisanal, inland and aquaculture fisheries activities, ii) to increase the value of fish exports by $15 \%$ annually focusing on strategic high-value markets such as the European Union (EU), iii) to promote and increase value addition activities on fish products, and iv) to promote and enforce sector-wide enhanced sustainable fishing practices and regulations..

In reviewing the fisheries section of The Agenda for Prosperity, there are, at least, three important issues for policy coherence-i) the overall goal is different to the policy outcome; ii) the strategic objectives appear to focus on productionist activities, which have been superseded by the objectives of the new fisheries policy; and iii) the relationship between the new sectoral fisheries policy and The Agenda for Prosperity is not explained (in either document), and while there are many commonalities, this situation could lead to confusion for future policy implementation.

Second, with regards to fiscal policy, one of the main objectives across all sectors is to enhance domestic 
revenue mobilisation [32]. The fisheries sector currently contributes USD 34 million (or 1\%) mainly from the sale of fishing licences in the industrial sector and from fishing access agreements sold to foreign vessels. The performance contracts of Ministers (under the results-based framework) specify the level of revenue generation expected each year [32]. In terms of policy coherence, it is not clear how the objective of revenue collection (through expanded fishing activity) will relate to the development and implementation of fisheries management systems (aimed at limiting fishing activity to reduce the risk of fisheries overexploitation [27]).

Third, in terms of governance reform under "The Agenda for Prosperity", local government will be empowered to direct sectoral activities and collect and use revenues [32]. Local government will regulate inshore fishermen and collect a licence fee. Once again, it is unclear whether the incentive to collect licence fees will be coherent with national fisheries management policy [27].

\subsection{What Is the Status of the Fisheries Management Systems?}

\section{Introduction}

The design and operation of effective fisheries management systems is a fundamental and core component of fisheries policy implementation. Unfortunately, the so-called "conventional" science-based approach focusing on fish (weight) production, using a government-directed command-and-control system and regulatory framework, has been largely unsuccessful worldwide, leading to the formation of regulated open-access fisheries threatened by both economic and biological overexploitation. Alternatively, fisheries management systems which focus on well-defined fishery management units, pay careful attention to the economics of exploitation, underpinned by an appropriate governance framework, based on a clear definition of roles, rights (incentives) and responsibilities, often show better levels of performance in all domains (economic, social and environment).

\section{Assessment}

The assessment score for fisheries management is $2 / 10$. Sierra Leone does not have an effective fisheries management system, and both the inshore and offshore fisheries are threatened by both economic and biological overexploitation. The fact that Sierra Leone has limited capability to patrol its own EEZ has made it highly vulnerable to illegal fishing from foreign fleets.

\section{Supporting information and analysis}

The current approach to fisheries management in Sierra Leone is shown by two key documents. First, under the Fisheries Policy and Operational Framework (2010) [27], a framework for management for each of three major fisheries is presented including i) small pelagic shared resources in the northern Gulf of Guinea Sub-region, ii) shrimp fishery in Sierra Leone, and iii) Sciaenidae and Sparidae fishery communities of the Gulf of Guinea.

The proposed management frameworks include measures to reduce fishing effort (through reduction of licence numbers, plus gear technical measures), strengthening of observer programmes, strengthening of Monitoring Control and Surveillance (MCS), strengthening of regional collaboration, measures to improve fisher livelihoods (alternative livelihoods, social infrastructure, service delivery), strengthening of fishers knowledge on responsible fishing, reduction of by-catch (through technical measures and alternative livelihoods), preservation of habitats through Marine Protected Areas (MPA) and enforcement of regulations, improvements of quality and quantity of catch (through technical measures and MCS), and increased stakeholder consultation for fisheries management plans.

Second, under “The Agenda for Prosperity (2013-18)" [32], fisheries management is included under Pillar 1 (Economic diversification) and Pillar 2 (Managing natural resources). Pillar 1 is entitled "Economic Diversification for Inclusive Growth". The Strategic Objective is to promote and enforce sector-wide enhanced sustainable fishing practices and regulations. Priority activities include supporting the establishment of wealth-based fisheries management systems, supporting fisheries conservation activities and regular fish stock assessments, continue to support regional initiatives through the West Africa Regional Fisheries Programme, and evaluate the sustainability of the fisheries sector. Pillar 2 is entitled "Managing Natural Resources". The Strategic Objective is to ensure the sustainable management of marine resources. The priority activities include establishment and management of marine protected areas (MPA), creating Community Management Associations (CMA), and improve systems of monitoring, control and surveillance for combating illegal, unreported and unregulated (IUU) fishing.

Despite this guidance, in reality fisheries management systems are weakly defined at present and fisheries management performance appears to be very weak. Although the current status of fisheries exploitation in Sierra 
Leone is not known precisely (due to a lack of data and analysis), it seems highly likely that inshore fish stocks are fully exploited, and probably overexploited, generating little or no net economic value. This includes valuable tropical demersal fish stocks, and small pelagics, along with shrimps. The inshore areas are fished by both small-scale (or artisanal) operators and large-scale commercial operators (beyond a declared Inshore Fisheries Exclusion Zone, IFEZ). The number of operators and level of fishing effort have increased significantly in recent years. The national fisheries management system operated de facto by the MFMR focuses on the issuing of fishing licences and enforcing fisheries regulations (gear types, fish types and seasons). But in reality, the administration lacks the capacity (human, technical, and financial) to implement its own fisheries management system. Attempts have been made to pilot alternative approaches inshore including Marine Protected Areas (MPA) and Community Managed Areas (CMA), with the support of the WARFP, but only at a limited scale. For the time-being, however, the majority of inshore fisheries appear to operate under free and open-access conditions, which inevitably has led to an increased risk of both economic and biological overexploitation.

For offshore fisheries, the situation is even more opaque, but equally worrying. With both demersal and pelagic stocks (small and large pelagic fish) in this area, a fleet of modern large-scale vessels are licensed to fish by the MFMR. While some of the vessels are owned by Sierra Leone citizens, other foreign-owned vessels (Asian origin) have secured licences through local (Sierra Leonean) agents; a joint-venture arrangement permitted under the current law. It is unclear whether there is a limit on the number of vessels which can be licensed, but there is every indication that an application for a licence is usually successful once the appropriate fee is paid. Until recently, there was very limited monitoring of licensed vessel activity, and there was no system for Monitoring, Control and Surveillance (MCS). In the last few years, a Vessel Monitoring System (VMS) has been installed, and operated under the WARFP. This has succeeded in protecting the IFEZ from large-scale vessels. But by and large, the offshore fisheries are operated by the licensed large-scale vessels without interference from the Ministry.

Two other issues are important. First, it is likely that a significant amount of the offshore fisheries catch is transshipped at sea, and exported without ever being inspected or being landed in Sierra Leone. Second, it also seems probable that there is a significant level of illegal fishing, especially at the border of the EEZ, where there is no enforcement of national jurisdiction (since Sierra Leone has no offshore patrol capability). There is a strong probability, therefore, that the offshore fisheries of Sierra Leone are also operating under free and openaccess conditions, with the fish stocks threatened by both economic and biological overexploitation.

Overall, the policy documents (above) demonstrate a good awareness of the importance of governance in general, and the central role of fisheries management in policy implementation, along with the importance of stakeholder participation and rights. All of these areas are important in considering future fisheries governance reform. However, the operationalization of the policy framework, through the design and implementation of appropriate fisheries management systems has been weak. It can be argued that while much of the policy development work so far has been useful, it remains at a strategic level, and there is only limited guidance or explanation on how a fishery could be managed in reality. There is an urgent need, therefore, to set up a fisheries management planning process for Sierra Leone, focusing on 2 or 3 fisheries to start, and gradually bringing in more and more fisheries over time, building upon demonstrable success and lesson-learning.

\subsection{Is There a Well-Defined Strategic Work-Plan for Policy Implementation?}

\section{Introduction}

An effective process of fisheries policy implementation will require coordination between the various stakeholders involved, the planning and provision of key inputs (both soft and hard investments), and the management of an array of functions and processes directed towards achieving the key policy outcomes. In the first instance, the fisheries ministry will take responsibility for public inputs and finances relating to the fisheries sector. The relationship between the public sector and the private sector within a particular policy setting will also need to be worked out and specified. At a macro- and strategic level, the sequence of inputs and investments for successful policy implementation is critically important.

\section{Assessment}

The overall assessment for the strategic work-plan is 5/10. Further clarification and refinement of the current work-plan for the future development of the sector in Sierra Leone is urgently required.

\section{Supporting information and analysis}

At present, guidance on a strategic work-plan for fisheries policy in Sierra Leone is available from at least 
three sources, as follows:

First, the Policy and Operational Framework for Fisheries of Sierra Leone (2010) [27]. The Achievable Outcome is stated as "Ecologically sustainable and economically efficient fisheries". There are five proposed outputs as follows i) Conservation and sustainable use (Strategy e.g. Establish realistic licensing scheme), ii) Increased application of co-management mechanisms (e.g. Better understanding of stakeholders), iii) Diversification and increased international fish trade (e.g. Hygiene and sanitation controls), iv) Delivery of cost-effective and efficient management (e.g. Human capacity building), and v) Development of sustainable aquaculture (e.g. Private sector involvement encouraged).

Second, The Agenda for Prosperity (2013-2018) [32]. The Goal is defined as "A sustainable fisheries sector which primarily ensures food security and increased jobs for Sierra Leonean men and women, and in addition begins to maximise opportunities for value addition and export to strategic and competitive markets". The Strategic Objectives include i) To increase the supply of fish for the domestic market by at least $15 \%$ annually particularly from the semi-industrial, artisanal, inland and aquaculture fisheries activities (e.g. Operationalise four landing sites), ii) To increase the value of fish exports by $15 \%$ annually focusing on strategic high-value markets such as the EU (e.g. Operationalise fish testing laboratory), iii) To promote and increase value addition activities on fish products (e.g. Establish fish processing facilities), and iv) To promote and enforce sector-wide enhanced sustainable fishing practices and regulations (e.g. Establish wealth-based fishery management systems).

Third, the NEPAD Sierra Leone, Fisheries Strategy to 2030 (2013) [33]. The Goal is defined as "Ecologically sustainable and economically efficient fisheries". The Purpose is defined as frameworks, processes and capacities established and operational in public and private sectors, and civil society. This will enable the planning, design and implementation of appropriate fisheries development and management policies, the basis of a new governance framework. Key activities will include i) Enablement of fisheries stakeholders (fishing communities, private companies, civil society) to maximise opportunities and develop the sector, ii) Fisheries and aquaculture management systems established, and iii) Trade and Finance relevant to fisheries sector in place, and iv) Information, Infrastructure and Technology are acquired and operational.

There are four important issues to be considered. First, each of the three works-plans have some similarities (e.g. the emphasis on sustainable fisheries), but also important differences (plans "a" and "b" are more strategic in nature, whereas "c" has been further developed into a more detailed 5-year plan with a schedule, budget and sequencing). Second, two plans (a and b) build upon a conventional government-oriented approach to input supply to the sector, whereas the other (c) focuses on re-orienting the governance framework and enabling a wide range of stakeholders to develop the sector. Third, work-plan "a" is the oldest, and it may be less relevant given the changing national context, whereas work-plan "b" and "c" are more contemporary, but there are some coherence issues-although "b" is part of the overall national development policy strategy, it can be argued that it is not well-aligned with international best practice in fisheries management compared to "c". Fourth, the existence of these three detailed documents requires a firm clarification from the MFMR concerning its future plans for the sector, to avoid any confusion amongst stakeholders.

\subsection{Is There Sufficient Institutional Capacity for Policy Implementation?}

\section{Introduction}

The successful implementation of fisheries policy in any country will be dependent on having sufficient institutional capacity in place, along with other factors such as finance and political support. As a core institution, the fisheries management authority may be in the public sector, or some sort of co-management arrangement between the public sector and other stakeholders, or may even be private. Management authority functions may be vested in more than one body, and include the formulation of policy, ensuring that the knowledge needed for informed decision making is acquired (e.g. stock assessments, economic analysis of the fishery, a poverty profile of communities), ensuring that harvesting regulations and other management decisions are based on sound science, providing opportunities for stakeholder participation in fisheries management, general administration, and monitoring compliance, ensuring enforcement and, where appropriate, dispute settlement.

\section{Assessment}

The overall assessment for institutional capacity is $2 / 10$. Both the public and the private sector organisations in Sierra Leone lack the capacity and capabilities to implement fisheries policy and operationalise an effective fisheries management authority. Capacity-building should therefore be a top priority for the future. 


\section{Supporting information and analysis}

In Sierra Leone, a future fisheries management authority is likely to involve public and private organisations. At present, the MFMR is the most prominent organisation, along with a number of private fishing companies, and two fishermen's organisations.

The MFMR was the subject of a recent management and functional review (MFR) [34]. This concluded the following:

"The capacity and capability of the Ministry in 2012 has barely changed from its 2006 levels. It remains woefully under-capacity in terms of mid-level (Grade 7 to 11) and senior (Grade 12 above) professionals. The Ministry should be credited for effective coordination of the Joint Maritime Committee, and for transcending the civil service cultural inertia to cross-agency communication and collaboration. Overall however, it has to be said that in its current state the Ministry does not have the capability and capacity to lead the fisheries and aquaculture sector effectively into the future. Building such a capability will take some time and require transitional support". (Pages 3 and 4)

The MFR goes on to make a series of recommendations to address the situation including the establishment of a new directorate structure to address core functions and services (policy and strategy, fisheries management, services and research, fish quality, and compliance), separation of the process of policy development and management from its implementation (and especially the critical regulatory function of licensing from the process of enforcing the regulatory framework), and seeking immediate support from the Public Sector Reform Unit to assist in the development of a change management programme to implement the MFR including securing Cabinet approval. Detailed proposals to enable an immediate capacity build within the new Ministry include a programme funded under the World Bank West Africa Regional Fisheries Project (WARFP).

It should be noted that the MFMR suffered significantly as a result of the civil war (1991-2002), including the destruction of buildings and data/research records. Thereafter, commendably, many staff continued in their duties without salaries and under conditions of great uncertainty.

With regards to the private sector, there are ten fishing companies based in Sierra Leone, operating industrial fishing vessels and engaged in the fish export trade. A number have foreign (Asian) partners under a joint-venture arrangement. There is a "Fishing Company Association" based in Freetown, and its representative acts as a conduit for communication to the MFMR, attending key meetings and consultations. The association does not have any formal role as part of the current fisheries management authority, and appears to have limited capacity.

The two national fishermen's associations-Sierra Leone Artisanal Fishermen's Union (SLAFU) and Sierra Leone Amalgamated Artisanal Fishermen's Union (SLAAFU)—also participate in meetings and consultations. However, they are also thought to lack the capacity to engage at a higher level.

\subsection{Is There Appropriate Finance and Investment Available for Policy Implementation?}

\section{Introduction}

Policy implementation in fisheries, as with any other sector, implies investment costs for both public and private sector stakeholders. Well-managed and valuable fisheries are capable of generating sufficient benefits to repay any initial upfront public capital investments (e.g. infrastructure such as harbours), to provide a source of cost-recovery for future re-current costs (e.g. fisheries authority functions such as MCS and quality control), and to give a profitable return on capital overall. Stakeholder organisations from both the public (e.g. Ministry of Fisheries) and private sectors (e.g. seafood firms) will need to work-out and assess the investment opportunity presented by the fisheries sector, and determine the appropriate level of finance and investment required over time. Given the high opportunity cost of capital in most countries, the decision to invest in the fisheries sector, as opposed to alternatives, will have to be made carefully, and based on the best available information.

\section{Assessment}

The overall assessment score for appropriate finance and investment is $4 / 10$. There are a number of strategic work-plans (above) for future fisheries development in Sierra Leone, but there is a need to agree a single costed plan, and to ensure that finance and investment plans are coherent with this. There are important lessons to be learned from past experiences in Sierra Leone and elsewhere in this regard.

\section{Supporting information and analysis}

The question of whether there is adequate finance and investment available for fisheries policy implementation in Sierra Leone can be examined from a number of perspectives. 
First, the available assessments indicate that the fisheries sector is a good area for future investment. The potential capitalised economic value of the marine fish stocks alone is estimated to be USD 735 million, capable of generating annual economic benefits of USD 59 million (above).

Second, the potential value of Sierra Leone's fisheries has been well-recognised by government and the private sector. The fisheries sector has a prominent role in the government's "The Agenda for Prosperity" [32]. At the same time, both domestic and foreign investors continue to seek access to valuable marine fish stocks—most significantly the GoSL has recently signed a fishing agreement with the Russian Federation [35]. However, there is little information or analysis, in the public domain, concerning private sector investment in the fisheries sector in Sierra Leone.

In terms of risk, investors must consider at least two important factors which affect the viability of investments (i.e. the ability to provide a competitive return on capital) - the security of fish supply from well-managed fisheries, and the operation of an effective marketing (value-) chain-both of which require strengthening at a national level in Sierra Leone-and should be priorities for public investment also.

Third, there exists a documented track-record for public investment in the fisheries sector (Table 6). A review for the World Bank [36] revealed that since 2006, some USD 50 million has been made available from different sources including the African Development Bank, the European Union, World Bank and others. However, major investments had only been made recently and the sector appears to have been starved of investment overall. It was also revealed that the performance of the interventions had been relatively weak overall (Table 7). The review study concluded that it seemed highly unlikely that a sufficient "critical mass" of enabling core interventions have been undertaken to either allow take up of the "opportunities” present by the fisheries sector (especially international trade) for development in Sierra Leone, or to address the serious "challenges" which the sector now faces, especially the lack of well-managed fisheries and the IUU theft of national fisheries wealth.

Fourth, given the recent track record (above), and the resulting weak "at risk" status of the sector, the definition of "appropriate” finance and investment should therefore encompass not only the level of funding involved, but also how it used and the general context and conditions. It is critical that a future strategic work-plan is worked out carefully and that the prioritization and sequencing of activities forms the basis for the implementation process.

Fifth, it can be asserted, therefore, that the current status of the sector is related to the mis-match between development plans and finance and investment. For instance, there has been an emphasis on capital investment for infrastructure, and very limited attention to governance reform and capacity-building. This pattern has been witnessed in many countries for a number of reasons - the domination of the fish production maximisation policy narrative, the opportunistic nature of national governments and politicians (to secure investments) and the role of external donors and private sector investors (to push loans).

\subsection{Is There Support in Place from National, Regional and International Organisations?}

\section{Introduction}

The development of a fisheries sector in any country will often need the help and support of a range of organisations in areas such as general leadership, technical advice, planning, finance, institutional design and capacity-building. Specific opportunities and challenges may need to be addressed at national, regional and international levels.

\section{Assessment}

The overall assessment score for support from organizations is 4/10. While there is some support for the fisheries sector in Sierra Leone at all levels (national, regional, international) covering key areas (technical, financial, institutional, capacity building and policy implementation), it remains relatively weak and patchy. There is also a high level of uncertainty regarding current and possible future donor investments.

\section{Supporting information and analysis}

In Sierra Leone, at the national level, the MFMR is the lead government organisation for the fisheries sector, and its role has already been examined earlier in this paper. Other government organisations also take an interest in the fisheries sector-including the Ministry of Finance, National Revenue Authority and Ministry of Planning-but the lead still comes from the MFMR. The national policy on development "The Agenda for Prosperity” (above) sets the direction for all sectors, while the national fisheries policy provides specific guidance. In general, there is regular interaction between the MFMR and these other government organisations, but it is arguable 
Table 6. Sierra Leone-fisheries sector-developments and interventions since 2006.

\begin{tabular}{|c|c|c|c|c|}
\hline \multirow[t]{2}{*}{ No. } & \multirow[t]{2}{*}{ Date } & \multicolumn{3}{|c|}{ Project Profiles ${ }^{\mathrm{a}}$} \\
\hline & & Title & Institution/Funding & Status \\
\hline (1) & 2003-2010 & $\begin{array}{l}\text { Artisanal Fisheries Development } \\
\text { Project (Focus: Official Quality } \\
\text { Control in the Artisanal Fisheries } \\
\text { Sector-Infrastructure) }\end{array}$ & $\begin{array}{c}\text { African Development Bank } \\
\text { and Government of Sierra } \\
\text { Leone. } \\
\text { The total amount disbursed at } \\
\text { PC was ADF Loan: } \\
\text { 8,996,878,000 Unit of } \\
\text { Account (UA); GoSL } \\
\text { 701209.75 UA }\end{array}$ & $\begin{array}{c}\text { Project completed. } \\
\text { Overall evaluation rating: } 3 \\
\text { [Good-_espite a few shortcomings]; } \\
\text { Four fish receiving centres built on } \\
\text { coast (landings and post-harvest } \\
\text { infrastructure)—-not in use at present; } \\
\text { capacity building and research; credit } \\
\text { facilities; }\end{array}$ \\
\hline$(2)$ & 2007-2011 & $\begin{array}{l}\text { Institutional Support and Fisheries } \\
\text { Management Project } \\
\text { (Focus: Fisheries Resource } \\
\text { Assessment) }\end{array}$ & $\begin{array}{l}\text { European Union } \\
\text { Euro } 3 \text { million }\end{array}$ & $\begin{array}{l}\text { Project completed. } \\
\text { Improved knowledge and status of } \\
\text { some stocks achieved, although studies } \\
\text { of important inshore stocks (shrimp } \\
\text { and small pelagics) were deficient; }\end{array}$ \\
\hline (3) & 2011-2016 & $\begin{array}{c}\text { West African Regional Fisheries } \\
\text { Programme in Sierra Leone } \\
\text { (Focus: Resource Governance, } \\
\text { Reduction of Illegal Fishing and } \\
\text { Official Quality Control \& Value } \\
\text { Addition) }\end{array}$ & $\begin{array}{c}\text { World Bank } \\
\text { US } \$ 28 \text { million (loan) }\end{array}$ & $\begin{array}{l}\text { Project suspended in } 2014 \text { in Sierra } \\
\text { Leone. } \\
\text { Key activities to date: Canoe } \\
\text { registration scheme and } \\
\text { co-management initiatives; MCS } \\
\text { system established and operational; } \\
\text { preparations for harbour development; }\end{array}$ \\
\hline (4) & 2009 & $\begin{array}{l}\text { Modernising Sierra Leone’s } \\
\text { Fisheries Legal Framework } \\
\text { (Focus: Legal review) }\end{array}$ & $\begin{array}{l}\text { FAO-TCP } \\
\text { US } \$ 600,000\end{array}$ & $\begin{array}{c}\text { Project completed } \\
\text { Analysis and review of legal } \\
\text { framework and production of a new } \\
\text { draft Fisheries Bill (awaiting approval) }\end{array}$ \\
\hline (5) & 2012-2014 & $\begin{array}{l}\text { West African Pilot Project } \\
\text { (WAPP) in Sierra Leone. } \\
\text { (Focus: Legal and Policy Reform) }\end{array}$ & $\begin{array}{l}\text { NEPAD } \\
\text { US } \$ 1.4 \text { million }\end{array}$ & $\begin{array}{c}\text { Project completed } \\
\text { Analysis of legal framework; advice } \\
\text { on new Fisheries Bill; collaboration in } \\
\text { developing fisheries management } \\
\text { system; design of five year plan for } \\
\text { fisheries development. }\end{array}$ \\
\hline (6) & 2007-2012 & $\begin{array}{l}\text { The West African Quality } \\
\text { Programme. } \\
\text { (Focus: Strengthen enterprise } \\
\text { competiveness, compliance with } \\
\text { international trade rules and } \\
\text { technical regulations) }\end{array}$ & $\begin{array}{c}\text { European Union } \\
\text { Euro } 8 \text { million (sub-regional) }\end{array}$ & $\begin{array}{l}\text { Project completed: } \\
\text { Attempted to ensure product } \\
\text { certification, standards and } \\
\text { accreditation. However, fish products } \\
\text { remain unacceptable to the EU market. }\end{array}$ \\
\hline (7) & 2012 & $\begin{array}{l}\text { The Precon experiment } \\
\text { (Focus: Effect official controls) }\end{array}$ & $\begin{array}{c}\text { MFMR/GoSL } \\
\text { US } \$ 600,000 \text { (initial support) }\end{array}$ & $\begin{array}{c}\text { On-going } \\
\text { To develop strategies to enable access } \\
\text { to EU fish market }\end{array}$ \\
\hline (8) & 2011-2015 & $\begin{array}{l}\text { Technical Capacity Building in } \\
\text { Fishing and Seafood Processing } \\
\text { Technology Project in Sierra } \\
\text { Leone } \\
\text { (Focus: Develop national human } \\
\text { resource capacity in fishery sector } \\
\text { to manage for optimum revenue } \\
\text { generation and sustainability) }\end{array}$ & $\begin{array}{c}\text { Russian Federation } \\
\text { Implemented by UNIDO and } \\
\text { MFMR } \\
\text { US } \$ 1.47 \text { million }\end{array}$ & $\begin{array}{c}\text { Completed } \\
\text { Training in various specialties at } \\
\text { middle-level under the supervision of } \\
\text { the University of Sierra Leone }\end{array}$ \\
\hline
\end{tabular}

${ }^{\mathrm{a}}$ Source: World Bank DTIS [36].

whether the fisheries sector is simply seen as a "cash-cow" (through selling fishing licences and fishing agreements, as well as collecting fines from vessels arrested for fishing illegally) by many of them (including local government), while the real development potential is being overlooked.

Other national level organisations include the University of Sierra Leone, especially Fourah Bay College with its specialised Institute for Marine Biology and Oceanography (IMBO)—which provide technical support (e.g. 
Table 7. Sierra Leone-DTIS action matrix—fisheries sector-progress since $2006^{\mathrm{a}}$.

\begin{tabular}{|c|c|}
\hline Programme Objective Performance & Specific Actions \\
\hline Fully achieved & Improve fishery infrastructure \\
\hline Partially achived & $\begin{array}{l}\text { - Establish preconditions for conclusion of fisheries agreements; } \\
\text { - } \quad \text { Prepare for improved access to foreign fish markets. } \\
\text { - } \quad \text { Demplete EU access conditions List } 1 \text {; } \\
\text { - } \quad \text { Make MCS effective; } \\
\text { - Improve sector governance; Develop aquaculture; }\end{array}$ \\
\hline Not achieved & $\begin{array}{l}\text { - Develop a fisheries strategy in collaboration with the Strategic Partnership; } \\
\text { - } \quad \text { Prepare for negotiation of fisheries agreements; } \\
\text { - } \quad \text { Evaluate effectiveness of fishing agreements; Develop action plan for next } 5 \text { years; }\end{array}$ \\
\hline
\end{tabular}

${ }^{\mathrm{a}}$ Source: World Bank, DTIS [36].

fish stock assessment and economic analysis) and capacity-building (e.g. graduate and post-graduate programmes). There is relatively little NGO support for fisheries in Sierra Leone, except for the Environmental Justice Foundation (EFJ) which has focused on IUU issues. Within the private sector, the SLAFU and SLAAFU (small-scale fishers) and the organisation for industrial fishing companies participate in national meetings and interact with government, but mostly on an ad hoc basis, and all these organisations lack capacity to really engage within a fully-fledged fisheries management system. In terms of financial support, national banks have very limited interaction with the sector, except for day-today operation of bank accounts for individuals and firms. There is no specific provision for lending to the fisheries sector.

At a regional level, Sierra Leone shares important fish stocks (e.g. shrimp, tuna and small pelagics) with neighbouring countries (e.g. Liberia, Guinea). Sierra Leone is a member of the Fisheries Committee of the West Central Gulf of Guinea (FCWC) and the Sub-Regional Fisheries Commission (SRFC), both which provide a forum to discuss key issues and propose actions. Other organisations which have some limited involvement in regional fisheries include the Manu River Union (MRU) and the Economic Organisation of West African States (ECOWAS). Both FAO and NEPAD have also had some involvement in regional initiatives in the past, and are both currently involved with the World Bank-funded West African Fisheries Programme for West Africa (WARFP), providing technical support. FAO is also currently disseminating and building capacity on the "Voluntary Guidelines on Responsible Governance of Tenure of Land, Fisheries and Forest in the Context of National Food Security”.

At an international level, Sierra Leone has received technical and financial support for fisheries development from a range of multi-lateral and bi-lateral organisations (Table 6). While much of this support has been wellintentioned on key issues, the overall performance has been weak (Table 7). The reasons for this outcome include the weak domestic institutional capacity to host major interventions, the lack of a joined-up approach to projects (there has been a lack of overall coherence between interventions), and a lack of political support for the interventions involved (along with political interference in project implementation). At present, the major investment provided by the World Bank through the West African Fisheries Programme for West Africa (WARFP), is both unfinished and suspended (pending an investigation into implementation irregularities). An investment by the Russian Federation focusing on capacity-building and fish processing - a large and active programme with good appraisal reviews-has recently been completed.

\section{Conclusions}

The total score for fisheries development potential in Sierra Leone, based on the assessment of the expert panel from the NEPAD-WAPP, using the "Freetown Fisheries Framework" is 41/100 (Table 8).

Therefore, the "state of readiness" of the fisheries sector in Sierra Leone to contribute to future national economic development is relatively weak. Unless some of the major issues, which have been discussed in this paper, are addressed in the near future, the full potential of the fisheries sector will not be realised. This is a very serious situation given the recognised need to re-activate national development policy ("The Agenda for Prosperity”), now that the Ebola virus epidemic has ended. 
Table 8. The Freetown Fisheries Framework for fisheries development-assessment results.

\begin{tabular}{lll}
\hline \multirow{2}{*}{ No. } & Assessment Results & Score \\
\cline { 2 - 3 } & Key Question & 4 \\
\hline 1 & Has the sustainable economic value of the fish stocks been determined? & 7 \\
3 & Is the national vision and strategy for the sector appropriate and agreed? & 7 \\
4 & Is there a well-defined fisheries policy? & 2 \\
5 & Does the fisheries law provide an enabling framework? & 2 \\
6 & Is there a high degree of policy coherence? & 5 \\
8 & What is the status of the fisheries management systems? & 2 \\
9 & Is there a well-defined work-plan for policy implementation? & 4 \\
\hline
\end{tabular}

The score card approach used in this paper enables the identification of the major strengths and weaknesses of the fisheries sector at present, the key issues which need to be addressed and the priority areas for targeted interventions. While many of the issues have been identified and discussed earlier in the paper, the authors believe that there are three key areas which require urgent attention by the Government of Sierra Leone and its development partners.

First, while the sustainable economic value of the marine fish resources of Sierra Leone has been estimated, there is a need to extend, update and improve this assessment. The current potential capitalised economic value is estimated at USD 735 million, capable of generating USD 59 million in economic rent per year. The potential contribution of a well-managed set of valuable fisheries to national GDP, economic growth, and social wellbeing, along with other direct benefits, especially food supply and employment, needs to be revealed and explained carefully to government policy makers, development partners and all stakeholders to provide a focus and target for collaborative development efforts. Within government itself, there is a need to increase the level of communication and understanding on key issues between relevant ministries (e.g. Fisheries, Finance and Planning) — to really understand what is at stake. It is the considered opinion of the authors that the current economic value, broadly defined, is probably an underestimate, and certainly does not include inland fisheries and aquaculture.

Second, the governance framework for fisheries development and especially for fisheries management remains incomplete in Sierra Leone. Despite a number of targeted projects in this area, and the participation of a wide range of stakeholders, the framework has not been finalised. Particularly critical issues are the establishment of an enabling legal framework and the design of effective fisheries management systems. Furthermore, fisheries institutions are weak-specifically the MFMR requires major reform and capacity-building. The Government of Sierra Leone and its development partners need to act quickly to address these issues since the governance framework and institutions are the fundamental foundations for future fisheries development.

Third, assuming that the two crucial factors above are tackled head-on, there is an urgent need to support a future fisheries development process in Sierra Leone through appropriate financial instruments and investments, technical inputs and capacity-building. The assessment of past investments and inputs reveals a weak level of performance, which provides important lessons for the future. In particular, there is a need to agree a single future fisheries development strategy and implementation plan which will determine both the level of investment required and the sequence of investments. In the past, infrastructure and technology investments have dominated and preceded the establishment of an adequate fisheries governance framework. This inevitably increased the risk of fisheries overexploitation and a loss of potential benefits. The implementation of an agreed development strategy will take time, measured in years, and may require the support and advocacy of key stakeholders, as so-called "champions for change", to maintain direction and momentum within the overall political process in- 
volved.

In summary, the opportunity presented by the fisheries sector to contribute to a better future in a Post-Ebola Sierra Leone has been widely recognised. However, the current paper shows that unless the state of readiness of the sector in key areas such as fisheries governance is addressed, it is unlikely that anything like its full potential will be realised.

\section{Acknowledgements}

The authors would like to acknowledge the help and support of the staff of the Government of Sierra Leone's Ministry of Fisheries and Marine Resources (MFMR), the African Union's New Partnership for Africa's Development (NEPAD) Fisheries Programme (funded by the United Kingdom's Department for International Development, DfID), the World Bank-funded West Africa Regional Fisheries Programme (WARFP) and all the fisheries stakeholders in Sierra Leone who gave so generously of their time in contributing to the work which underpins this paper. Dr. Sloans Chimatiro (NEPAD Fisheries Adviser) and Ms. Alushe Nditya (NEPAD Programme for African Fisheries, Coordinator), in particular, provided much needed helpful advice and guidance throughout. We are also grateful to Dr. Foday Turay (African Development Bank) for his comments on an earlier draft of the paper.

\section{References}

[1] World Health Organization (WHO) (2015) Situation Updates: Ebola Virus Disease. http://www.who.int/mediacentre/news/ebola/en

[2] British Broadcasting Corporation (BBC) (2015) Ebola: Mapping the Outbreak. http://www.bbc.co.uk/news/world-africa-28755033

[3] The Republic of Sierra Leone (Ministry of Health and Sanitation) (2015) Ebola Response Plan. http://health.gov.sl/?page id=874

[4] Global Humanitarian Assistance (2014) Humanitarian Funding Analysis: Ebola Outbreak in Sierra Leone. http://www.globalhumanitarianassistance.org/wp-content/uploads/2014/07/Final-GHA-Sierra-Leone-START-briefing. pdf

[5] World Bank Group (2015) Ebola Response Fact Sheet. http://www.worldbank.org/en/topic/health/brief/world-bank-group-ebola-fact-sheet

[6] World Health Organization (WHO) (2015) Statement (7 November 2015). http://www.afro.who.int/en/sierra-leone/press-materials/item/8139-who-commends-sierra-leone-for-stopping-ebola-vir us-transmission.html

[7] World Bank Group (2015) Ebola: Most African Countries Avoid Major Economic Loss but Impact on Guinea, Liberia, Sierra Leone Remains Crippling.

https://www.worldbank.org/en/news/press-release/2015/01/20/ebola-most-african-countries-avoid-major-economic-los s-but-impact-on-guinea-liberia-sierra-leone-remains-crippling

[8] United Nations Environment Programme (UNEP) (2010) Environment, Conflict and Peace-Building Assessment. Technical Report. http://postconflict.unep.ch/publications/Sierra_Leone.pdf

[9] African Development Bank (AfDB) (2013) SIERRA LEONE: Transitioning Towards Green Growth; Stocktaking and the Way Forward.

http://www.afdb.org/fileadmin/uploads/afdb/Documents/Project-and-Operations/Sierra\%20Leone\%20-\%20Transitioni ng\%20Towards\%20Green\%20Growth\%20-\%20Stocktaking\%20and\%20the\%20Way\%20Forward\%20-\%20Full\%20R eport.pdf

[10] World Bank Group (2015) Sierra Leone Country Profile. http://www.worldbank.org/en/country/sierraleone/overview

[11] United Nations Development Programme (UNDP) (2014) Human Development Report. http://www.undp.org/content/undp/en/home/presscenter/events/2014/july/HDR2014.html

[12] European Commission (EC) (2015) FOR-LEARN Expert Panels. http://forlearn.jrc.ec.europa.eu/guide/4 methodology/meth expert-panel.htm

[13] Department for International Development (DFID) (2015) Growth-Building Jobs and Prosperity in Developing Countries. DFID, London.

[14] United Nations Food and Agriculture Organization of the United Nations (FAO) (2008) Achieving Poverty Reduction through Responsible Fisheries. Lessons from West and Central Africa. FAO Fisheries and Aquaculture Technical Paper No. 513, FAO, Rome. 
[15] Cunningham, S., Neiland, A.E., Arbuckle, M. and Bostock, T. (2009) Wealth-Based Fisheries Management: Using Fisheries Wealth to Orchestrate Sound Fisheries Policy in Practice. Marine Resource Economics, 24, 271-287. http://dx.doi.org/10.1086/mre.24.3.42629655

[16] United Nations Food and Agriculture Organization (2014) Global Oceans Action Summit for Food Security and Blue Growth Opens in The Hague. http://www.fao.org/news/story/en/item/224779/icode/

[17] Cunningham, S. and Neiland, A.E. (2010) African Fisheries Development Aid. In: Leal, D., Ed., The Political Economy of Natural Resource Use: Lessons for Fisheries Reform, World Bank, Washington DC, 21-44.

[18] World Bank (2005) Good Management Practice in Sustainable Fisheries-A Series of 15 Key Sheets. http://siteresources.worldbank.org/INTARD/Resources/335807-1323958783967/8321851-1323959552668 /WBPolicyBrief12.PDF

[19] Wikipedia. Geography of Sierra Leone. https://en.wikipedia.org/wiki/Geography_of_Sierra_Leone

[20] Government of Sierra Leone (2008) Fisheries of Sierra Leone. Ministry of Fisheries and Marine Resources (MFMR), Freetown.

[21] The Economist (2014) The Economist Explains GDP. http://www.economist.com/blogs/economist-explains/2014/03/economist-explains-26

[22] Government of Sierra Leone (2014) Annual Report. Accountant General’s Department, Freetown.

[23] African Development Bank (AfDB), Organisation for Economic Development (OECD) and United Nations Development Programme (UNDP) (2014) African Economic Outlook: Sierra Leone. AfDB, Abidjan.

[24] Neiland, A.E., Arbuckle, M., Bodiguel, C., Bostock, T., Campbell, J., Gronnevet, L., Kaindaneh, P., Seisay, M. and Williams, L.O. (2007) Sierra Leone: A Proposed Fisheries Sector Strategy Paper (FSSP). United Kingdom Department for International Development (DFID), London, World Bank, Washington DC and United Nations Food and Agriculture Organisation (FAO), Rome.

[25] Frankel, J.A. (2010) The Natural Resource Curse: A Survey. National Bureau of Economic Research (NBER) Working Paper No. 15836, Cambridge.

[26] Government of Sierra Leone (2003) Fisheries Policy of Sierra Leone. Ministry of Fisheries and Marine Resources (MFMR), Freetown.

[27] Government of Sierra Leone (2010) Policy and Operational Framework for Fisheries of Sierra Leone. Ministry of Fisheries and Marine Resources (MFMR), Freetown.

[28] Government of Sierra Leone (2011) The Draft Fisheries Management and Development Bill. Ministry of Fisheries and Marine Resources (MFMR), Freetown.

[29] Government of Sierra Leone (1994) Fisheries Act. Ministry of Fisheries and Marine Resources (MFMR), Freetown.

[30] Baio, A., Coulibaly, D., Gitonga, N., Neiland, A.E. and Sei, S. (2012) West Africa Pilot Project-Sierra Leone (WAPP-SL) Fisheries Policy and Law in Sierra Leone: A Review of Current Status and the Identification of Future Reform Options. New Partnership for Africa’s Development (NEPAD), Midrand.

[31] Long, R. (2013) West African Pilot Project-Sierra Leone (WAPP-SL). Republic of Sierra Leone-Draft Fisheries (Conservation and Management) Bill 2011 (Revision 2). Redline Corrections for Consideration. New Partnership for Africa's Development (NEPAD), Midrand.

[32] Government of Sierra Leone (2012) The Agenda for Prosperity. Road to Middle Income Status. Sierra Leone's Third Generation Poverty Reduction Strategy Paper (2013-2018). Government of Sierra Leone, Freetown.

[33] Neiland, A.E. and Baio, A. (2013) West African Pilot Project-Sierra Leone (WAPP-SL) (Part 3). Sierra Leone Fisheries Strategy to 2030. New Partnership for Africa’s Development (NEPAD), Midrand.

[34] Government of Sierra Leone (2012) Management and Functional Review. Ministry of Fisheries and Marine Resources (MFMR), Freetown.

[35] Cole, M. (2013) The Republic of Sierra Leone Signs Fisheries Agreement with the Russian Federation in Moscow. http://www.sierraleoneembassy.ru/the-republic-of-sierra-leone-signs-fisheries-agreement-with-the-russian-federation-i n-moscow/

[36] Neiland, A.E. and Baio, A. (2013) Analysis of the Fisheries Sector for the Diagnostic Trade Integration Study (DTIS) for Sierra Leone. World Bank, Washington DC. 